\title{
The effect of critical material prices on the competitiveness of clean energy technologies
}

\author{
Alexandra Leader ${ }^{1}\left(\mathbb{D} \cdot\right.$ Gabrielle Gaustad $^{2} \mathbb{D} \cdot$ Callie Babbitt $^{1} \mathbb{D}$
}

Received: 5 March 2019 / Accepted: 20 May 2019 / Published online: 4 June 2019

(c) The Author(s) 2019

\begin{abstract}
Clean energy technologies are widely recognized as a part of the solution for a sustainable future. Unfortunately, these technologies often rely on materials that are considered critical because of their importance to the technology and their potential for supply disruptions, which often lead to drastic and unexpected price spikes. With many clean energy technologies still struggling to compete economically with incumbent technologies, it is uncertain if such material price changes could have a significant economic impact on overall clean energy technology costs. In this paper, we first estimate material intensity of critical materials for three case study clean energy technologies: proton exchange membrane (PEM) fuel cells in fuel cell electric vehicles (FCEVs), neodymium iron boron $(\mathrm{NdFeB})$ permanent magnets in direct drive wind turbines, and Li-ion batteries in battery electric vehicles (BEVs). Using these data, as well as material price information, we analyze technologylevel costs under potential material price spike scenarios. By benchmarking against target costs at which each technology is expected to become economically competitive relative to incumbent energy systems, we evaluate the impact of price spikes on marketplace competitiveness. For the three case studies, technological costs could increase by between 13 and $41 \%$ if recent historical price events were to recur at current material intensities. By analyzing the economic impact of material price changes on technology-level costs, we demonstrate the need for stakeholders to push for various supply risk reduction measures, which are also summarized in this paper.
\end{abstract}

Keywords Supply risk $\cdot$ Techno-economic analysis $\cdot$ Wind turbines $\cdot$ Li-ion batteries $\cdot$ Fuel cells $\cdot$ Rare earth elements

\section{Critical materials in clean energy technologies}

Clean energy technologies are essential tools for reducing carbon emissions and providing for a sustainable future. As new advancements are made in this field, we see a greater complexity of materials in high-tech products, some of which are critical in terms of both their importance to the technology's function and their potential for supply disruption [1]. Throughout this paper, we explore the concept

Electronic supplementary material The online version of this article (https://doi.org/10.1007/s40243-019-0146-z) contains supplementary material, which is available to authorized users.

Gabrielle Gaustad

gaustad@alfred.edu

1 Rochester Institute of Technology, 1 Lomb Memorial Drive, Rochester, NY 14623, USA

2 Alfred University, 1 Saxon Drive, Alfred, NY 14802, USA of critical materials and how their price instabilities may affect the ability of these clean energy technologies to compete in a tight marketplace, filled with low-cost incumbent technologies.

\section{Identifying critical materials and their importance for firms}

Critical materials are those that have both technological importance and some form of supply risk associated with their production and/or distribution. "Technological importance" includes uses in clean energy, defense, electronic, or healthcare technologies, where the functionality provided by a material cannot be easily replaced with substitutes. Supply risks are characterized by low availability of a material from recycling streams, the material being mined majorly as a byproduct of other materials, a limited number of suppliers, or the positioning of those suppliers in geopolitically unstable countries. An article by Graedel and Nuss quantitatively scores the criticality of 62 elements [2], and a review article

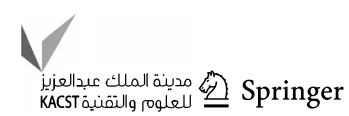


by Jin et al. is helpful in summarizing the findings of such studies [3]. While the methods of determining criticality vary between studies, and therefore elements are given differing quantitative or qualitative criticality "scores", we do see common trends in materials such as rare earth elements, platinum group elements, and individual elements including indium, gallium, tellurium, and cobalt, consistently being identified as more critical than most other elements for clean energy technologies [3]. Some examples of more prolific metrics used to measure criticality include those that quantify material resource availability, the price of the material, and market concentration. The demand for many materials identified as critical is expected to grow in the future, alongside the growth in world population, electronic sales, and clean energy adoption. High demand, coupled with criticality, promotes the risk of extreme price spikes or even material unavailability in the event of a disruption in the supply chain.

Many of these materials have extreme price inelasticity, which stems from the small quantities that are used in final products, allowing for the cost increase to be passed on by the intermediate purchaser to the final consumer. When a change in price does cause a change in demand, producers may be slow to change output due to the scale of operations, high capital requirements, long lead times for new projects, or the interconnected nature of mining (in which raw materials are not mined separately, but rather as byproducts and coproducts of one another) [4]. These factors, when combined, can lead to significant price spikes. A classic example of such a price spike was cobalt in the 1970s. During that time, approximately $65 \%$ of cobalt production occurred in Zaire (now the Democratic Republic of the Congo) [5]. Additionally, cobalt demand stemmed largely from samarium-cobalt permanent magnets and superalloys in jet engines. Around 1977, supply was disrupted due to an uprising in the region of production $[5,6]$. The market saw price increases of over $500 \%$, causing severe interruptions for the downstream cobalt users, such as General Electric [5]. Still today, over $50 \%$ of cobalt comes from that same region, and although prices have long since recovered, such a concentrated supply in a provenly unstable region leaves concern over the potential for another major supply disruption $[7,8]$.

It is in the interest of firms, consumers, and governments to reduce the risk of material supply disruptions and price spikes to maintain the competitiveness of clean energy technologies in the marketplace. While the motivations of these stakeholders may vary from simply being able to make a profit or purchase the technologies at a reasonable price to meeting greenhouse gas emissions targets at a national level, the goal of minimizing price increases remains the same. Therefore, this study examines the connection between material price instability, technology costs, and the potential solutions for minimizing the risk of material supply disruptions and price spikes.

\section{Clean energy case studies}

While other studies have considered the effect of material prices on clean energy technologies [9-12], this study is novel in its consideration of multiple technologies under the same methodology and the comparison to cost targets under various price spike scenarios. While varied in their implementation, similar economic modeling that extrapolates from price changes in material input prices to impact on product cost has been utilized in previous studies. For example, two studies consider indium and tellurium price changes and their impact on photovoltaic solar panel cost metrics [10-12]. A previous study has been conducted on Li-ion batteries by a private organization, and resultant data and findings are not publicly available to inform further research, technology design, or policy making. An article on this study by the Bloomberg New Energy Finance group, titled "Lithium Price Spike Has Moderate Effect on Batteries," suggests that the report considers the effect of material prices on Li-ion battery cost for at least one type of Li-ion battery [9]. This present work extends the analysis to seven Li-ion battery chemistries, as well as to proton exchange membrane (PEM) fuel cells and neodymium iron boron $(\mathrm{NdFeB})$ permanent magnets for wind turbines. We take the concepts of commodity vulnerability and translate them beyond their impact on an individual firm to overall technology adoption. This approach is essential to bridge critical material studies and climate change mitigation strategies that involve unprecedented deployment of clean energy technologies.

Many studies consider material requirements on the basis of meeting various climate change mitigation targets [13-16]. These studies typically assess whether we have the quantity of materials necessary to manufacture clean energy technologies to the extent needed to mitigate climate change to various levels. For example, to deploy enough wind turbines and electric vehicles to keep atmospheric $\mathrm{CO}_{2}$ at $450 \mathrm{ppm}$, one study estimated that neodymium and dysprosium may experience an increase in demand of more than 700 and $2600 \%$, respectively (from 2010 numbers), by 2035 [13]. Another analysis identifies potential bottlenecks for critical materials in solar, wind turbines, fuel cells, batteries, electrolysis, hydrogen storage, electric vehicles, and efficient lighting through 2050 [14]. These authors identify silver followed by tellurium, indium, dysprosium, lanthanum, cobalt, platinum, and ruthenium, as potential bottlenecks that could render the Intergovernmental Panel on Climate Change renewable energy scenarios "partly unrealistic from the perspective of critical metals" [14]. When considering the quantity 
of materials that would be required to provide "all global energy with wind, water, and solar power," the literature indicates that such a system would likely not be inhibited by the availability of base materials, but other materials, such as neodymium, platinum, and lithium, would need to be recycled, substituted out, or extracted from new deposits [15]. In more specific cases such as that of tellurium in cadmium-tellurium (CdTe) solar cells, the literature again indicates that the critical material (tellurium) may indeed dampen the adoption of the technology [16]. For this particular case however, this is more likely to occur due to the byproduct nature of tellurium rather than its overall resource quantity [16].

While these studies provide a valuable perspective on material demand for clean energy adoption, the literature has yet to fully connect such estimates of material consumption with their attendant impacts on technology cost. Therefore, this study merges analysis of material intensity with scenarios capturing material price volatility to understand the ultimate impact on technology cost and adoption. If material supply is low, price increases will potentially lead to lower demand for, and adoption of, clean energy technologies. The three case study clean energy technologies analyzed are described below and shown conceptually in Fig. 1. We use cost as the metric of comparison as it is commonly cited as a main inhibitor for clean energy technology adoption [17]. Because each technology provides a unique functionality, it was necessary to normalize cost estimates consistently. Therefore, technology cost per functional output of the technology (in kWh energy stored or $\mathrm{kW}$ power generated) is used to compare clean energy technologies to their incumbent equivalent and determine their ability to compete economically in the energy market.
Proton exchange membrane fuel cells in fuel cell electric vehicles

Fuel cells come in many forms, typically classified by their electrolyte type, as that is what drives many other factors, such as what electrochemical reactions occur, what type of catalyst is used, which fuel is run, and the operating temperature at which it performs [18]. Fuel cells convert fuel directly to electricity without combustion. They are considered a clean energy technology because they are highly efficient in terms of energy conversion, can reduce air pollution and point source emissions of combustion byproducts, and are capable of running on fuels produced from renewable resources [18]. PEM fuel cells have a high power density, operate at relatively low temperatures compared to other fuel cell types, and start up quickly, making them ideal for vehicle applications [18]. Pure hydrogen is used as the fuel, and only $\mathrm{H}_{2} \mathrm{O}$ is emitted at the tailpipe. They rely on a platinum catalyst, which is a major downside to this technology, as platinum group elements are expensive and deposits concentrated enough for economic mining are rare [19]. Researchers are looking into methods such as carbon nanotube supported platinum catalyst to reduce platinum use in PEM fuel cells, which would thereby reduce costs [20,21]. In the fuel cell case study presented in this paper, we considered only PEM fuel cells for FCEVs, as other types such as solid oxide fuel cells (SOFC) and molten carbonate fuel cells (MCFC) are primarily used in stationary applications [18].

Proton exchange membrane fuel cells use platinum as a catalyst because of its high catalytic activity, selectivity, stability, and its resistance to poisoning by impurities [22, 23]. These properties and others such as its high value and resistance to tarnishing suit it to a wide array of end uses in gasoline-vehicle catalytic converters (45\%), jewelry (34\%),

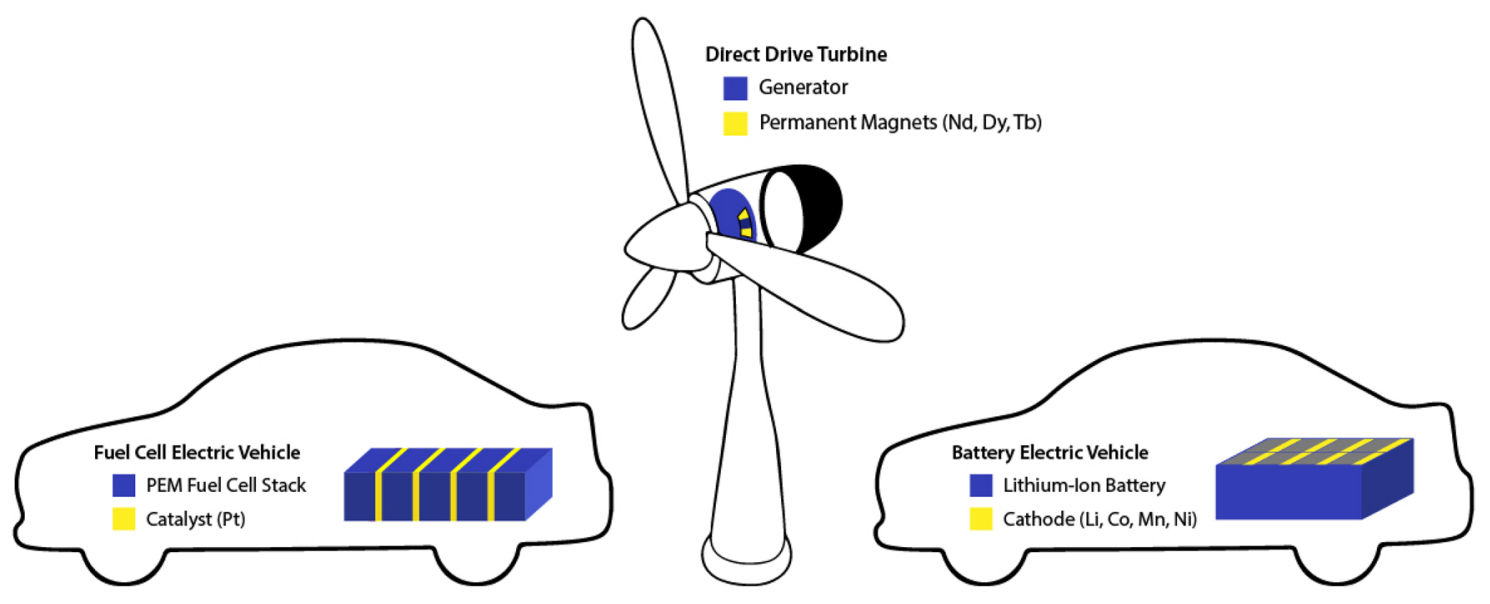

Fig. 1 Schematics of the three case studies considered in this work. From left to right: PEM fuel cell catalysts in fuel cell electric vehicles (FCEVs), NdFeB permanent magnets in generators in direct drive wind turbines, and Li-ion battery cathodes in battery electric vehicles (BEVs). The elements in parenthesis are those that are analyzed in this study as explained in subsequent sections 
and chemical and petroleum refining (9\%) [24]. The demand for platinum for fuel cell use is growing, and one report estimates that $7 \%$ of the world's platinum supply in 2030 could be required for fuel cells in the European Union [25]. However, the material is also described in the literature as being a concern due to its high cost, concentrated supply, and scarcity [15, 23, 25, 26]. According to United States Geological Survey, platinum group elements are among the rarest elements on earth and are found in earth crust in concentrations of around 0.5 parts per billion. Adding to the criticality of platinum is the high concentration of production in South Africa, accounting for 72\% in 2017 [24]. Based on these combined supply and demand factors, platinum is therefore selected as the material to be analyzed for the PEM fuel cell case study.

\section{Permanent magnet generators in direct drive wind turbines}

Wind turbines can be classified into two major categories: geared and gearless (direct drive). Gearless direct drive turbines operate best at low speeds and have the advantages of better overall efficiency, lower weight, and fewer maintenance requirements [27]. Geared turbines on the other hand will operate at higher speeds on smaller turbines $(<5 \mathrm{MW})$ and contain few or no rare earth elements [27]. In 2015, approximately $23 \%$ of the globally installed wind capacity relied on generators utilizing $\mathrm{NdFeB}$ permanent magnets (which can contain the rare earth elements neodymium, dysprosium, praseodymium, and terbium). The other $77 \%$ had electromagnetic generators utilizing steel and copper for their functionality, neither of which is considered critical materials [27]. The critical materials identified in the literature as potentially being present in these direct drive turbines are neodymium, dysprosium, nickel, molybdenum, praseodymium, and terbium [15, 28-34]. The molybdenum and nickel are found in the steel alloys of the turbines and are therefore not included in the permanent magnet generator (PMG) case study [29].

Pavel et al. estimate that $\mathrm{NdFeB}$ permanent magnets could be dematerialized from 29 to $32 \%$ neodymium and praseodymium to $25 \%$ and from 3 to $6 \%$ dysprosium to less than $1 \%$ by 2020 [27]. It is possible to substitute small amounts of praseodymium for neodymium in $\mathrm{NdFeB}$ magnets to reduce cost and corrosivity; however, most literature combines any praseodymium material use with neodymium material content [26]. Direct substitution for the rare earths doesn't currently appear feasible; however, efforts are focused on finding new magnet compositions and/or using different components that don't rely on rare-earth-containing permanent magnets at all [27].

Neodymium, dysprosium, and terbium are considered in more detail in this case study of permanent magnets in direct drive wind turbines. These three elements are all rare earth elements (REEs). REEs are critical, largely because of their high production concentration in China, where approximately $81 \%$ of which were produced in 2017 [35]. Adding to REE criticality is the fact that currently less than $1 \%$ of REEs are recycled from the products they are used in [36]. In general, heavy REEs such as dysprosium and terbium are less abundant and therefore usually demand a higher value. According to the United States Geological Survey, "the magnet sector is expected to become the leading user of REEs, based on mass, by 2020" [35].

\section{Li-ion batteries in battery electric vehicles}

When comparing reusable batteries, factors such as safety, weight, efficiency, cycle life, and energy density should be taken into consideration [37]. Li-ion batteries are expected to lead the battery electric vehicle revolution, due primarily to their energy densities, which surpass those of other options, such as nickel metal-hydride (NiMH) or lead-acid batteries [37]. While NiMH batteries are currently the dominant battery choice for hybrid electric vehicles, some expect numbers as high as $70 \%$ of hybrid electric, and $100 \%$ of plug-in and full BEVs to use Li-ion batteries by 2025 [38]. Li-ion batteries have also been modeled as having lower environmental impacts than NiMH options when the technologies are compared on a "per-energy storage basis" [24] and an overall low contribution to the total BEV life cycle environmental impact [25].

Typically, Li-ion batteries contain a graphite anode and lithium-containing cathode [37]. Common cathodes include $\mathrm{LiFePO}_{4}$ (LFP), $\mathrm{Li}[\mathrm{NiCoAl}] \mathrm{O}_{2}$ (NCA), $\mathrm{Li}[\mathrm{MnNiCo}] \mathrm{O}_{2}$ (NMC), $\mathrm{LiMn}_{2} \mathrm{O}_{4}$ (LMO), and typically in non-vehicle uses, $\mathrm{LiCoO}_{2}$ (LCO) [37]. Different cathode chemistries provide different properties, each with their own drawbacks in terms of weight, material use, and cost. LFP batteries have good safety and long lifespans but lack the specific energy that some of the other chemistries can provide and are therefore often used in specialty applications, such as replacing the lead-acid starter battery [39]. NCA batteries provide high energy and power densities and have a moderate lifespan, making them good options for powertrains in electric vehicles; however, cost and safety are drawbacks [39]. NMC batteries are a fast-growing category due to their very high specific energy and high specific power. The active materials—nickel, manganese, and cobalt—can be blended at varying concentrations to give slightly different properties to suit either electric vehicles or energy storage applications [39]. In this study we will consider NMC batteries with Ni:Mn:Co ratios of 1:1:1, 6:2:2, and 8:1:1. NMC batteries can also be used in combination with other battery types such as LMOs. LMO batteries are less often used alone, but can commonly be found in conjunction with NMC batteries to enhance the current required for acceleration, while the NMC portion 
of the battery gives the vehicle the sought after long range [39]. Compared to the traditional LCO batteries, LMO batteries are cheaper, have a high electrochemical potential, and contain less potentially harmful materials [40]. LCO batteries are used in electronics such as cell phones and laptops due to the very high specific energy, but the short lifespans, limited thermal stability, high price of cobalt, and low specific power make LCO less than ideal for electric vehicle applications [39]. Li-ion batteries have the potential to contain dysprosium, praseodymium, neodymium, cobalt, manganese, nickel, lithium, terbium, and vanadium $[15,26$, $41,42]$. We select to analyze in this Li-ion battery case study the four major critical cathode materials used in Li-ion batteries which are lithium, cobalt, manganese, and nickel, recognizing that within these four materials, lithium and cobalt are identified as being the primary concerns [15].

Lithium is considered a geochemically scarce metal, found in earth's crust in concentrations of less than $0.01 \%$ by weight $[43,44]$. It is produced from natural brines and ore, and is also found in seawater, although currently it is not feasible to use seawater as a production source [43]. Salt lakes are currently the largest source of lithium production, largely found in Chile, Argentina, the USA, and China [43, 44]. With respect to ore mining, lithium is primarily produced from spodumene, in countries such as Australia, Brazil, Portugal, China, the USA, Canada, and Zimbabwe [43, 44]. The final method of lithium production is through secondary production, or recycling; however, this segment makes up less than $1 \%$ of production [43]. Recycling remains limited due to low lithium prices, dispersive applications (such as glass, ceramics, and lubricants), and an industrial focus on recovering other materials, such as cobalt, copper and nickel, at battery end-of-life [43]. Lithium demand is projected to grow over the coming century, particularly due to its use in Li-ion batteries for mobility applications [43-45]. Lithium is the lightest solid metal and has the highest electrochemical potential, making it ideal for battery applications as it can have a high energy density [44]. As of 2013, the battery sector was the second highest consumer of lithium at $23 \%$ of the world supply, second only to the ceramics and glass sector at $31 \%$ [44].

Over half of all cobalt is mined in the Democratic Republic of the Congo (DRC), with smaller percentages coming from China and Canada [7, 8]. It is mined mainly as a byproduct of nickel production or a co-product of copper production, with only $6 \%$ being attributed to primary production [7]. As mentioned previously, having such a high concentration of production in the historically unstable DRC has proved problematic and led to price spikes of over $500 \%$ as a combined result of institutional inefficiency and conflict in the area $[5,7]$. In fact, cobalt exports from the DRC actually halted altogether briefly during the 1970 s conflict [7]. China is also a large player in cobalt production, as they import partially refined cobalt from the DRC and complete much of the refining within their borders. In recent years, China has also been the world's largest user of cobalt as they rapidly grow their battery industry. Around 50\% of current cobalt production goes into rechargeable batteries, including those in electronic devices, electric vehicles, and energy storage applications [46]. The other 50\% is divided among applications such as catalysts, healthcare technologies, other electronic components, alloys, inks and pigments [46].

Manganese and nickel are less frequently described as being of concern; however, as the other main materials used in Li-ion battery cathodes in electric vehicles, we have chosen to include them in this analysis as well. Manganese is largely produced in South Africa, Australia, and Brazil as a primary material; however, a small percentage is also mined as a byproduct of iron $[47,48]$. It is primarily used in the steelmaking industry [49]. Nickel is mined in the greatest quantities in the Philippines, followed by Australia, Canada, and Russia [47]. Similarly to manganese, nickel is mined almost exclusively as a primary material; however, a small portion of production can be considered a byproduct of platinum production [48]. The largest end use demand for nickel is in stainless steel manufacturing [50].

\section{Methods}

The goal of this study was to determine potential impacts of critical material price spikes on the cost of clean energy technologies, using the three case study technologies as examples. Critical materials were selected based on those that have been identified through literature review for each technology to be critical or of concern as described in "Critical materials in clean energy technologies". Within each case study, material prices are varied to simulate the impact that changes in material price can have on the technology cost. For each case, we analyze the impacts both of changing all considered material prices simultaneously as well as the impact of independently manipulating the prices of individual materials. We then use a scenario of a recent historical price event in combination with current material intensities to demonstrate the impact of such a price spike reoccurring. As discussed in the introduction, each of the three case study technologies contain materials that are prone to these price changes.

\section{Material intensity calculations}

Material intensity is the mass of a given critical material per a functional unit associated with the technology of interest and its clean energy application. For wind turbine PMGs and PEM fuel cells, the functional unit is power $(\mathrm{kW})$, reflecting the use of these technologies in electric power generation

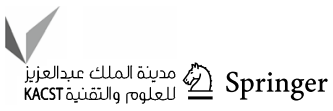


and fuel cell vehicle propulsion, respectively. For Li-ion batteries, the functional unit is energy storage $(\mathrm{kWh})$, representing its application in BEVs. Critical material compositions of each case study product were collected from an extensive literature review and normalized to the stated functional units provided in each respective literature source (see Supplemental Material Tables S2 and S3). Material intensities were calculated for platinum for the catalyst material in PEM fuel cells in FCEVs, neodymium, dysprosium, and terbium in permanent magnets used in the generators of direct drive wind turbines, and lithium, cobalt, manganese, and nickel in seven commercially available cathode chemistries used in Li-ion batteries for BEVs.

\section{Economic impact modeling}

Economic modeling was used to determine how supply disruptions, leading to various levels of price fluctuation, could impact the overall cost of a PEM fuel cell, a wind turbine PMG, and a Li-ion battery. Fundamentally, this model estimated the total system cost $(C)$ of clean technologies $(j)$, accounting for the material intensity $(M)$ of each technology, the material prices $(P)$, and a ratio $(R)$ of the critical material costs to the total technology system cost (Eq. 1): a proxy for the total cathode cost. This assumption neglects cost of any "other" cathode active materials including aluminum in NCA cathodes and iron in LFP cathodes as they are not considered critical and they were each found to make up less than $1 \%$ of the active cathode material costs [55-57]. Values used for all parameters can be found in Table 1.

By establishing the relationships between material and technology costs, we then could model the effect of material price fluctuation on technology costs. These analyses were performed for both the scenario of all the selected critical materials in the case study changing price at the same rate, and for each material changing price independently. These scenarios were also analyzed based on the degree to which material price fluctuations may cause clean energy to deviate from target cost parity with incumbent technology options. For the case of the PEM fuel cell, we compare to a 2020 target set forth by the United States Department of Energy Fuel Cell Technology Office of $\$ 40 / \mathrm{kW}$ [72]. For the direct drive wind turbine PMG target, cost scenarios are plotted against a target to meet the 2020 levelized cost of energy goals set by the European Wind Industrial Initiative to meet the Strategic Energy Technology (SET) Plan of $\$ 141 / \mathrm{kW}$ [73]. Finally, for the Li-ion batteries we consider a current average value of $\$ 209 / \mathrm{kWh}$ for $\mathrm{Li}$-ion electric vehicle bat-

$C_{j}=\left[\sum_{i}\left(M_{i} \times P_{i}\right)\right] \times\left[\frac{1}{R_{j}}\right]\left\{\begin{array}{l}\text { for } \quad j=\text { Fuel cell, } i=\mathrm{Pt} \\ \text { for } j=\text { Wind turbine, } i=\mathrm{Nd}, \mathrm{Dy}, \mathrm{Tb} \\ \text { for } j=\mathrm{Li} \text { - ion batteries, } i=\mathrm{Li}, \mathrm{Co}, \mathrm{Mn}, \mathrm{Ni}\end{array}\right\}$.

Material intensity $(M)$ was estimated as described in "Material intensity calculations" above. The baseline current material prices $(P)$ were obtained from Argus [51], InfoMine [52], MineralPrices.com [53], and USGS [54] and are specific to the years 2017 or 2018 (as summarized in Supplemental Materials Table S1). The relationship between the critical materials' prices and the total technology cost was calculated using literature and estimation approaches that varied slightly between technologies, based on data availability. For the PEM fuel cell and wind turbine PMG, estimates for system cost $(C)$ were readily available in the needed form $(\$ / \mathrm{kW})$, and $R$ could be solved for relative to other terms in Eq. 1. The $R$ value is calculated for use as a constant in the analysis when we calculate the effect of changing material price $(P)$ on system cost $(C)$. For Li-ion batteries, system cost data (in $\$ / \mathrm{kWh}$ ) were not available because the chemistry type is not typically provided for values in the literature. However, estimates have been published regarding the relative contribution of the battery cathode to the total battery cost, specific to each chemistry. Thus, we assumed that the price of obtaining the four major cathode materials, lithium, cobalt, manganese, and nickel, would be teries and the future (2025-2030) target of $\$ 100 / \mathrm{kWh}$ for Refs. [74-76]. The $\$ 100 / \mathrm{kWh}$ price point is largely seen as a "tipping point" for BEV adoption and has been described by McKinsey \& Company as the point at which "[electric vehicles]...reach true price parity with ICE vehicles (without incentives)" [75, 76].

The resulting analyses were benchmarked against recent material price fluctuations associated with recent historical events. The benchmark years selected were obvious examples of the greatest price fluctuations in the past 15 years. For the PEM fuel cell and Li-ion battery case studies, we examine the example of the 2008 global economic crisis. Although lithium prices were actually lower in 2008, cobalt, manganese, nickel, and platinum all experienced significant price spikes $[52,77]$. For the wind turbine case study, however, we chose to model the impact of the 2011 material price spikes, when rare earth element prices, including neodymium, dysprosium, and terbium, all increased sharply due to export limitations put in place by China [78]. The historical price data were combined with current material intensities to demonstrate how such a price change occurring again would affect the present cost of the technology. 
Table 1 Values used for each of the case study clean energy technology's economic calculations

\begin{tabular}{|c|c|c|c|c|c|c|}
\hline Technology $(j)$ & $\begin{array}{l}\text { Technology cost, \$/ } \\
\mathrm{kW}\left(C_{j}\right) \\
\text { Sources: [58-61] }\end{array}$ & $\begin{array}{l}\text { Technology compo- } \\
\text { nent }\end{array}$ & Element $(i)$ & Price, $\$ / \mathrm{kg}(P)$ & $\begin{array}{l}\text { Average material } \\
\text { intensity, } \mathrm{kg} / \mathrm{kW}(M)\end{array}$ & Sources $(P$ and $M)$ \\
\hline PEM fuel cell system & 55 & Catalyst & $\mathrm{Pt}$ & $\$ 26,715.60$ & 0.0002 & {$[15,62,63]$} \\
\hline Technology $(j)$ & $\begin{array}{l}\text { Technology cost, \$/ } \\
\text { kW }\left(C_{j}\right) \\
\text { Sources: [64-67] }\end{array}$ & $\begin{array}{l}\text { Technology compo- } \\
\text { nent }\end{array}$ & Element $(i)$ & Price, $\$ / \mathrm{kg}(P)$ & $\begin{array}{l}\text { Average material } \\
\text { intensity, } \mathrm{kg} / \mathrm{kW}(M)\end{array}$ & Sources $(P$ and $M)$ \\
\hline $\begin{array}{l}\text { Direct drive wind } \\
\text { turbine generator }\end{array}$ & 209 & Permanent magnet & $\begin{array}{l}\mathrm{Nd} \\
\mathrm{Dy} \\
\mathrm{Tb}\end{array}$ & $\begin{array}{r}\$ 39.40 \\
\$ 261.00 \\
\$ 655.00\end{array}$ & $\begin{array}{l}0.185 \\
0.021 \\
0.008\end{array}$ & $\begin{array}{l}{[15,28-32,51]} \\
{[28-30]} \\
{[33,34,53]}\end{array}$ \\
\hline Technology $(j)$ & $\begin{array}{l}\text { Material contribution } \\
\text { to system cost }\left(R_{j}\right) \\
\text { Sources: }[68-71]\end{array}$ & $\begin{array}{l}\text { Technology compo- } \\
\text { nent }\end{array}$ & Element $(i)$ & Price, $\$ / \mathrm{kg}(P)$ & $\begin{array}{l}\text { Average material } \\
\text { intensity, } \mathrm{kg} / \mathrm{kWh}(M)\end{array}$ & Sources $(P$ and $M)$ \\
\hline $\begin{array}{l}\text { Li-ion battery } \\
\text { (NMC111) }\end{array}$ & 0.196 & $\begin{array}{l}\text { NMC111 cathode } \\
\text { active materials }\end{array}$ & $\begin{array}{l}\mathrm{Li} \\
\mathrm{Co} \\
\mathrm{Mn} \\
\mathrm{Ni}\end{array}$ & $\begin{array}{r}\$ 73.94 \\
\$ 64.24 \\
\$ 2.04 \\
\$ 13.43\end{array}$ & $\begin{array}{l}0.118 \\
0.313 \\
0.292 \\
0.312\end{array}$ & $\begin{array}{l}{[7,41,54,55]} \\
{[7,52,55]} \\
{[7,52,55]} \\
{[7,52,55]}\end{array}$ \\
\hline $\begin{array}{l}\text { Li-ion battery } \\
\text { (NMC622) }\end{array}$ & 0.157 & $\begin{array}{l}\text { NMC622 cathode } \\
\text { active materials }\end{array}$ & $\begin{array}{l}\mathrm{Li} \\
\mathrm{Co} \\
\mathrm{Mn} \\
\mathrm{Ni}\end{array}$ & $\begin{array}{r}\$ 73.94 \\
\$ 64.24 \\
\$ 2.04 \\
\$ 13.43\end{array}$ & $\begin{array}{l}0.100 \\
0.170 \\
0.159 \\
0.508\end{array}$ & $\begin{array}{l}{[7,52,55]} \\
{[7,52,55]} \\
{[7,52,55]} \\
{[7,52,55]}\end{array}$ \\
\hline $\begin{array}{l}\text { Li-ion battery } \\
\text { (NMC811) }\end{array}$ & 0.133 & $\begin{array}{l}\text { NMC811 cathode } \\
\text { active materials }\end{array}$ & $\begin{array}{l}\mathrm{Li} \\
\mathrm{Co} \\
\mathrm{Mn} \\
\mathrm{Ni}\end{array}$ & $\begin{array}{r}\$ 73.94 \\
\$ 64.24 \\
\$ 2.04 \\
\$ 13.43\end{array}$ & $\begin{array}{l}0.090 \\
0.076 \\
0.071 \\
0.608\end{array}$ & $\begin{array}{l}{[7,54,55]} \\
{[7,54,55]} \\
{[7,54,55]} \\
{[7,54,55]}\end{array}$ \\
\hline Li-ion battery (NCA) & 0.194 & $\begin{array}{l}\text { NCA cathode active } \\
\text { materials }\end{array}$ & $\begin{array}{l}\mathrm{Li} \\
\mathrm{Co} \\
\mathrm{Mn} \\
\mathrm{Ni}\end{array}$ & $\begin{array}{r}\$ 73.94 \\
\$ 64.24 \\
\$ 2.04 \\
\$ 13.43\end{array}$ & $\begin{array}{l}0.106 \\
0.117 \\
0.000 \\
0.618\end{array}$ & $\begin{array}{l}{[7,41,54,55]} \\
{[7,52,55]} \\
{[7,52,55]} \\
{[7,52,55]}\end{array}$ \\
\hline Li-ion battery (LCO) & 0.308 & $\begin{array}{l}\text { LCO cathode active } \\
\text { materials }\end{array}$ & $\begin{array}{l}\mathrm{Li} \\
\mathrm{Co} \\
\mathrm{Mn} \\
\mathrm{Ni}\end{array}$ & $\begin{array}{r}\$ 73.94 \\
\$ 64.24 \\
\$ 2.04 \\
\$ 13.43\end{array}$ & $\begin{array}{l}0.112 \\
0.959 \\
0.000 \\
0.000\end{array}$ & $\begin{array}{l}{[7,41,54,55]} \\
{[7,41,52,55]} \\
{[7,52,55]} \\
{[7,52,55]}\end{array}$ \\
\hline Li-ion battery (LMO) & 0.103 & $\begin{array}{l}\text { LMO cathode active } \\
\text { materials }\end{array}$ & $\begin{array}{l}\mathrm{Li} \\
\mathrm{Co} \\
\mathrm{Mn} \\
\mathrm{Ni}\end{array}$ & $\begin{array}{r}\$ 73.94 \\
\$ 64.24 \\
\$ 2.04 \\
\$ 13.43\end{array}$ & $\begin{array}{l}0.097 \\
0.000 \\
0.103 \\
0.000\end{array}$ & $\begin{array}{l}{[41,54,55]} \\
{[52,55]} \\
{[52,55]} \\
{[52,55]}\end{array}$ \\
\hline Li-ion battery (LFP) & 0.114 & $\begin{array}{l}\text { LFP cathode active } \\
\text { materials }\end{array}$ & $\begin{array}{l}\mathrm{Li} \\
\mathrm{Co} \\
\mathrm{Mn} \\
\mathrm{Ni}\end{array}$ & $\begin{array}{r}\$ 73.94 \\
\$ 64.24 \\
\$ 2.04 \\
\$ 13.43\end{array}$ & $\begin{array}{l}0.087 \\
0.000 \\
0.000 \\
0.000\end{array}$ & $\begin{array}{l}{[52,55]} \\
{[52,55]} \\
{[52,55]} \\
{[52,55]}\end{array}$ \\
\hline
\end{tabular}

More details on sources, calculations, and ranges can be found in the Supplemental Materials

The historical pricing data used are not adjusted to account for time value as we are presenting an estimation of price change impacts. The details on the price data collected can be found in Supplemental Materials Table S6, and the results of the historical cases are presented alongside the previously discussed economic modeling results.

\section{Results and discussion}

\section{Case study 1: catalysts for PEM fuel cells in FCEVs}

As demonstrated in Fig. 2, the range of material intensities found in literature for platinum in PEM fuel cells and neodymium, dysprosium, and terbium in $\mathrm{NdFeB}$ permanent 


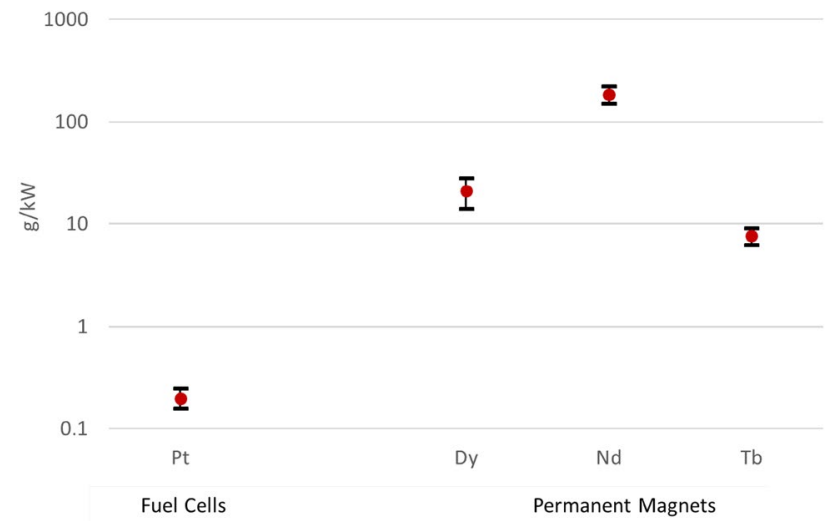

Fig. 2 PEM fuel cell and NdFeB permanent magnet material intensities. Note the log scale on the $y$ axis upon which the material intensities are presented. Sources [15, 28-34, 62, 63]

magnets are all tightly grouped. The ranges are shown with low, average and high intensities, on a log scale.

As the only critical material being considered for the PEM fuel cell case study is platinum, Fig. 3 can be read very simply as the effect of changing platinum price (on the $x$ axis) on the overall fuel cell system cost (in $\$ / \mathrm{kW}$ on the $y$ axis). As previously described, the results are compared to a 2020 target set forth by the United States Department of Energy Fuel Cell Technology Office [72]. In addition, we show the fuel cell system cost that would be experienced based on current material intensities, but under the most recent large price spike in platinum prices which occurred in 2008 during the global economic crisis. The 2008 price values are not adjusted for inflation (as described in the methods section) because we are presenting an estimation of impacts from this scenario. We find that if the 2008 platinum price spike were to occur again, it could cause a $17 \%$ increase in the fuel cell system cost. Platinum price decreases cannot alone reduce PEM fuel cell costs down to the $\$ 40 / \mathrm{kW}$ target, based on the platinum cost contribution of $\$ 5.33 / \mathrm{kW}[15$, $52,62,63]$ and overall fuel cell system cost of $\$ 55.00 / \mathrm{kW}$ [58-61]; however, mitigating platinum price spikes is a step in the correct direction as seen in Fig. 3.

While the $177 \%$ increase in platinum prices that occurred in 2008 would translate to a $17 \%$ fuel cell system cost increase under current PEM fuel cell material intensities, this is a large improvement from where the technology material costs would have been under material intensities just a decade ago. According to the US Department of Energy, platinum group metal intensities have gone down by approximately $80 \%$ in PEM fuel cells since 2005, due to active dematerialization efforts [72]. If the 2008 historical price event shown in Fig. 3 was to be calculated using the material intensities of fuel cells in 2008 in addition to the increased 2008 platinum prices, we would see fuel cell system costs $30 \%$ greater than those of 2018 .

\section{Case study 2: NdFeB permanent magnets in direct drive wind turbine generators}

The material intensities for the three materials, neodymium, dysprosium, and terbium that are being considered in the PMG case study are displayed in Fig. 2. For direct drive wind turbine PMGs, we consider the effect of the change in price of all three materials at the same rate (on the $x$ axis)

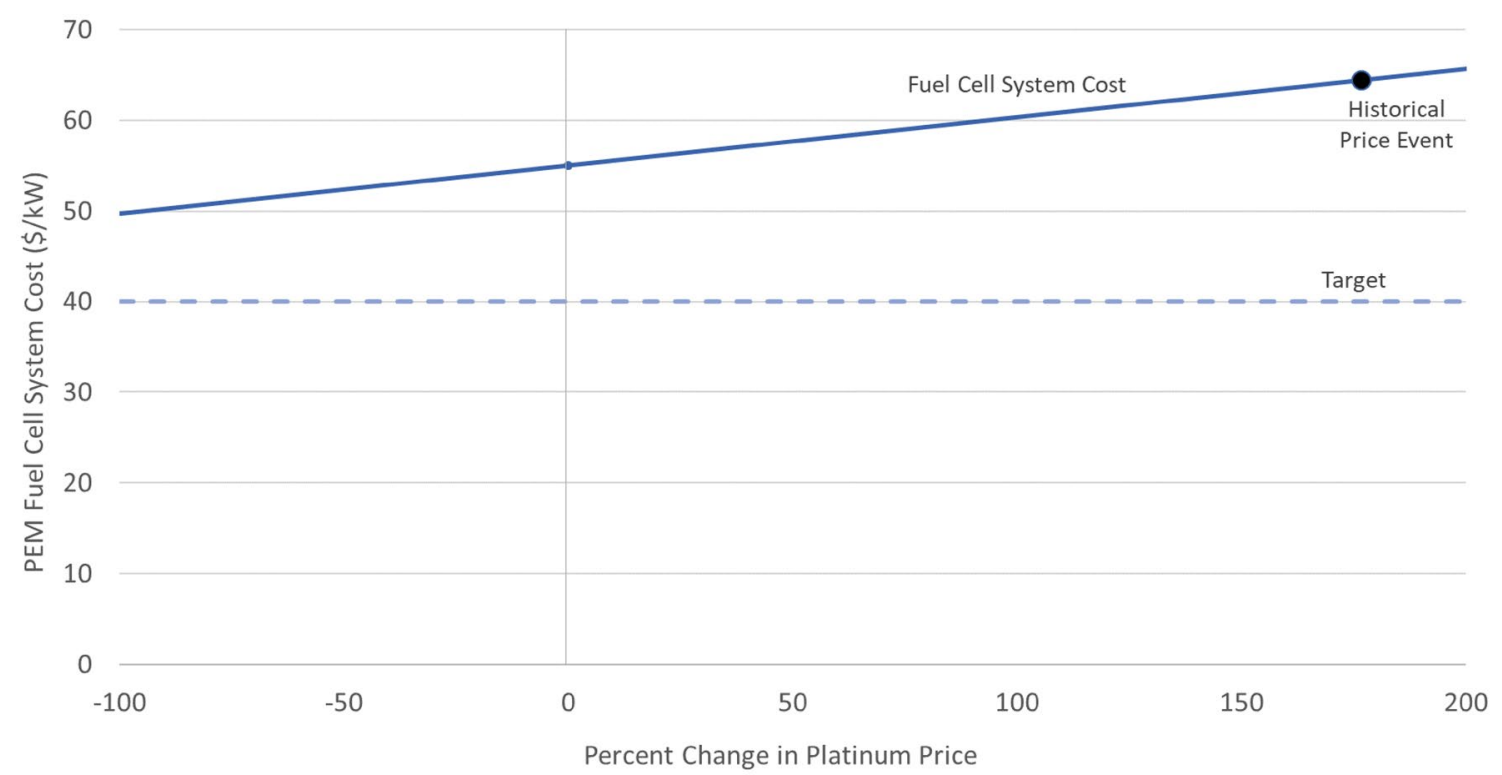

Fig. 3 Impact of platinum price changes on the overall PEM fuel cell system cost. The black dot is representative of the fuel cell costs that could occur under a scenario of current platinum intensities experiencing the platinum price spike that occurred in 2008. Sources: [52, 72] 
on the change in technology cost (in $\$ / \mathrm{kW}$ on the $y$ axis). This change in technology cost is compared to the target PMG cost of $\$ 141 / \mathrm{kW}$ which would allow the technology to meet the 2020 levelized cost of energy goals set by the European Wind Industrial Initiative to meet the Strategic Energy Technology (SET) Plan [54]. We also indicate in Fig. 4 the PMG cost that would have occurred based on current material intensity data but 2011 price data, when rare earth elements experienced a price spike due to export limitations put in place by China [78]. Again, these 2011 price values are not adjusted for inflation, as they provide an estimation of impacts from this scenario. In 2011, neodymium, dysprosium, and terbium were 685,613 , and $420 \%$ of their 2018 prices, respectively $[52,79]$. This would have led to a $41 \%$ increase in PMG costs from $\$ 209 / \mathrm{kW}$ to $\$ 295 / \mathrm{kW}$.

In addition to studying the effect of the three materials prices changing at the same rate, we also analyze the effect of a $100 \%$ price increase in each of the individual materials on the cost of the overall PMG in the table insert in Fig. 4. For example, it reads that a $100 \%$ increase in the price of neodymium would only lead to a $3.5 \%$ increase in the PMG cost, with all other material prices held constant. There is not a large variation in the effect of each of the three material's individual $100 \%$ price increases on the overall PMG cost. This is because neodymium is used in much higher concentrations but is less costly, while both dysprosium and terbium are used in smaller quantities but have higher costs. While it is not possible to achieve the designated target through material cost reductions alone based on permanent magnet neodymium costs of $\$ 7.29 / \mathrm{kW}$, dysprosium costs of $\$ 5.48 /$ $\mathrm{kW}$, terbium costs of $\$ 4.98 / \mathrm{kW}$, and average baseline PMG cost of $\$ 209 / \mathrm{kW}$ [64-67], mitigating price spikes is a preventative measure to reduce movement in technology costs away from the identified target. Details on material prices for the current and historical example can be found in the Supplemental Materials.

\section{Case study 3: cathode materials in Li-ion batteries for electric vehicles}

The material intensities of lithium, cobalt, manganese and nickel vary widely across the seven Li-ion battery chemistries modeled (Fig. 5). This variation is associated with technology age, battery capacity, manufacturer differences, and the overall quality of literature data. Lithium has the least variation across chemistries, because the lithium atom content characterizes the maximum storage capacity of the battery. On the other hand, cobalt has the highest variation, ranging from zero (in LMO and LFP batteries which use other metals in the cathode) to an average of $959 \mathrm{~g} / \mathrm{kWh}$ in LCO batteries. Nickel and manganese are each found in four of the seven chemistries and have a large spread of intensities between those four in which they are found. An interesting trend that can be clearly seen is that of the increasing nickel intensity and decreasing manganese and cobalt intensity from NMC111 to NMC622 and finally to NMC 811 (where the numbers following "NMC" represent the ratio of Ni:Mn:Co). It is important to understand that our results consider the overall change in material intensity in $\mathrm{g} / \mathrm{kWh}$; however, this change is affected by both dematerialization and efficiency improvements, which are not discernable with the single metric. This tradeoff of replacing manganese and

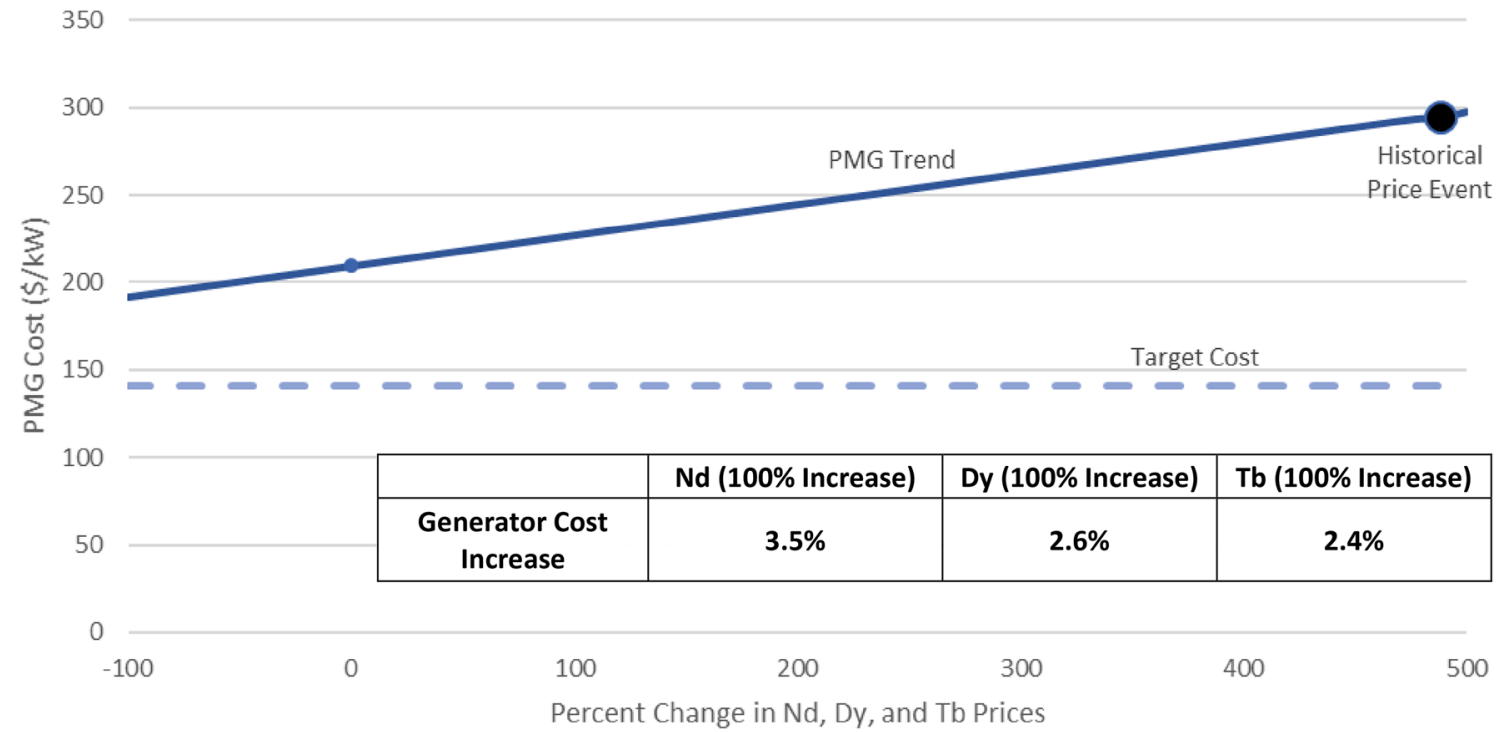

Fig. 4 Impact of permanent magnet material price changes on overall PMG cost $(\$ / \mathrm{kW})$. The black dot indicates the historical price event example where we show the effects of the 2011 material price increases (combined with current material intensities) on the PMG cost. Sources: [52, 53, 64-67, 79, 80] 

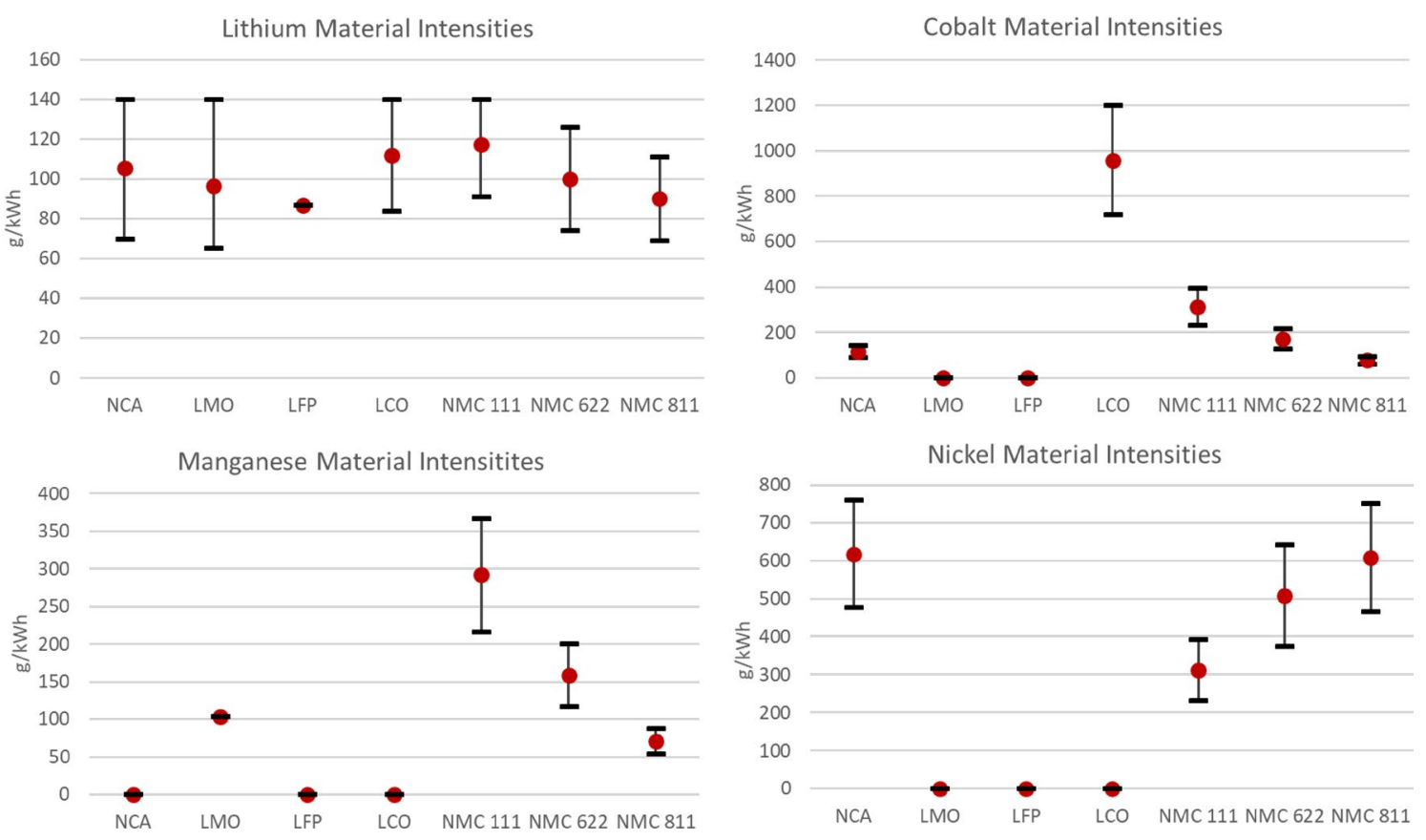

Fig. 5 Material intensities of lithium, cobalt, manganese, and nickel in seven different Li-ion battery chemistries. Note the differing $y$ axis scales. Sources [7, 41, 55]

cobalt quantities with greater nickel concentrations is sought after in the Li-ion battery industry largely due to the high cost and supply risks associated with cobalt use. There are also other benefits of replacing cobalt with greater amounts of nickel, including lower toxicity and the ability to increase capacity, tap density, and volumetric energy density [81].

In the baseline case, with current material prices, most of the overall battery costs are approximately in the \$60-230/ $\mathrm{kWh}$ range, where we would expect with the current average Li-ion battery cost of $\$ 209 / \mathrm{kWh}$ [74]. The LCO battery has a much higher cost due to its high cobalt content, but LCO batteries are more commonly used in consumer electronics, less so in BEVs. We have indicated in Fig. 6 the future (2025-2030) target of $\$ 100 / \mathrm{kWh}$ for Refs. [75, 76]. While some battery chemistries are currently below the target line, it is important to recall that they have different properties and applications.

To demonstrate the real possibility of these price spikes occurring, we have again analyzed the effect of the price changes that occurred in each of the four materials during the 2008 global economic crisis, under current material intensities. The impact of this historical price event example on each Li-ion chemistry is shown by the black dots on each of the chemistry lines in Fig. 6. As previously mentioned, the 2008 price values are not adjusted for inflation, as we are presenting an estimation of impacts from this scenario. The differential between 2018 and 2008 was $216 \%$ lower Li prices, as well as $81 \%$ higher Co prices, $165 \%$ higher Mn prices, and 272\% higher Ni prices [52, 77]. Detailed information on the pricing data used can be found in Supplemental Materials Table S6. The combination of these price changes would cause a cost increase of $13 \%$ in NMC111 batteries, $14 \%$ in NMC622 batteries, $15 \%$ in NMC811 batteries, $19 \%$ in both LCO and NCA batteries, and a decrease in cost of $2 \%$ in LMO batteries and $8 \%$ in LFP batteries. For all battery chemistries, with the exception of LFP and LMO, we observe that a price event similar to that which occurred in 2008 would increase the Li-ion battery costs, moving them away from the target that has been set for achieving their competitiveness with incumbent gasoline powered vehicles. In the case of LFP and LMO batteries, because lithium prices make up the majority of the cathode costs, and lithium prices have increased since 2008, the historical scenario actually led to decreases in battery costs as seen in Fig. 6.

While Fig. 6 demonstrates how the cathode materials all changing price at the same rate impacts the overall battery cost, the heat map in Fig. 7 allows us to observe how price fluctuations in a single material will impact battery cost independently. Here we display the impact of a $100 \%$ increase in each material's price (with all other material prices being held constant). This analysis could be done for any percentage, and the results will scale linearly. To identify the greatest sensitivity to price variability, results are color-coded, where green shows battery cost increases of less than 5\%; yellow represents battery cost increases of $5-10 \%$; orange shows battery cost increase of $10-15 \%$; and red reflects battery cost increases greater than $15 \%$. 


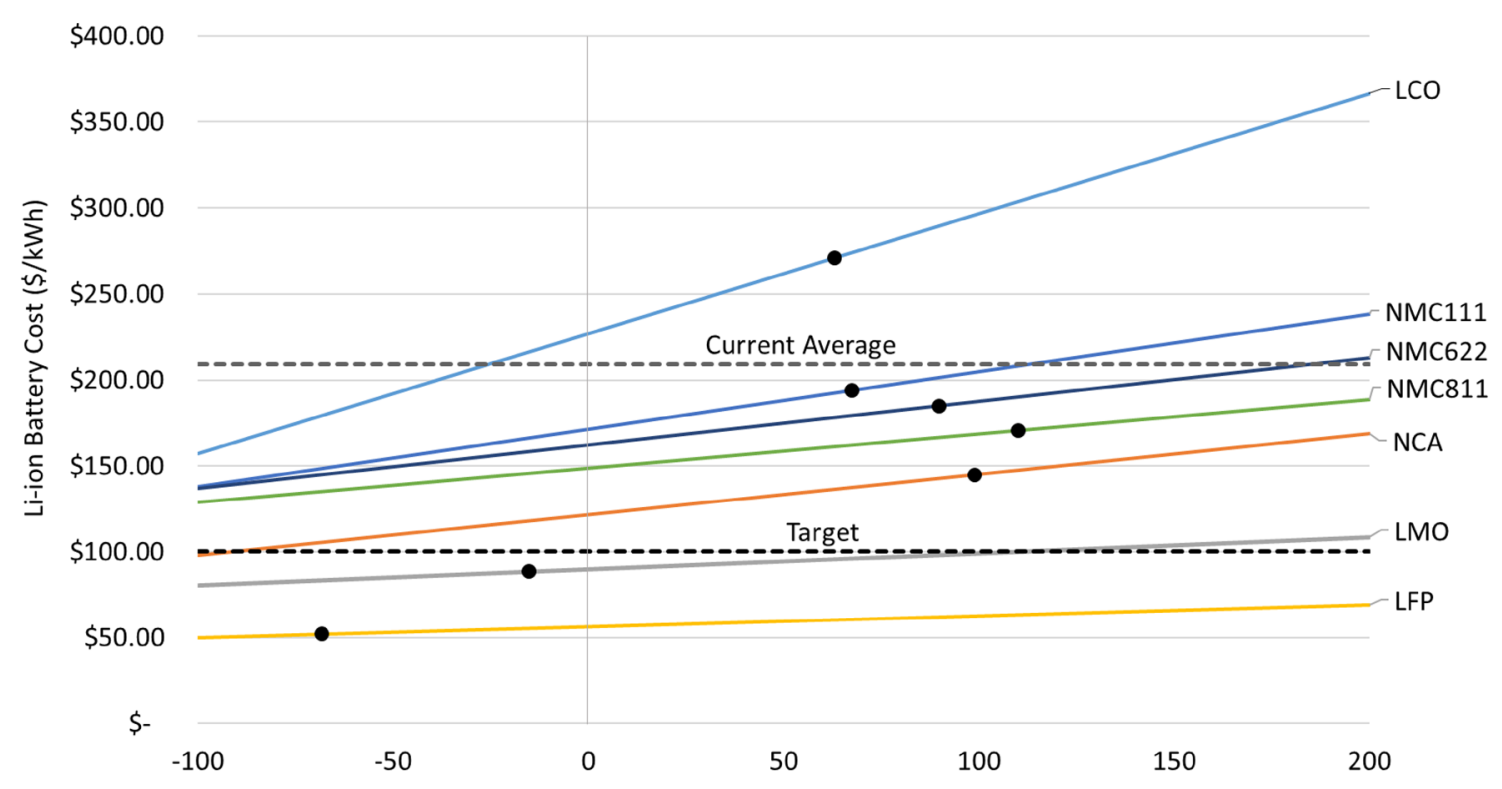

Percent Change in $\mathrm{Li}, \mathrm{Co}, \mathrm{Mn}$, and Ni Prices

Fig. 6 Impact of cathode material price changes on overall Li-ion battery cost. The percent change in material price on the $x$ axis assumes the same change is applied to all four materials being considered. The black dots on each of the chemistry lines are representative of the bat- tery costs that would have occurred if the current material intensity scenarios experienced the material prices of 2008. Sources [52, 69, $70,82,83]$

\begin{tabular}{|c|c|c|c|c|}
\hline & Li (100\% increase) & Co (100\% increase) & Mn (100\% increase) & $\mathrm{Ni}$ (100\% increase) \\
\hline NMC 111 & $5.1 \%$ & $11.7 \%$ & $0.3 \%$ & $2.4 \%$ \\
\hline NCA & $6.4 \%$ & $6.2 \%$ & $0.0 \%$ & $6.8 \%$ \\
\hline LMO & $8.0 \%$ & $0.0 \%$ & $2.3 \%$ & $0.0 \%$ \\
\hline LFP & $11.4 \%$ & $0.0 \%$ & $0.0 \%$ & $0.0 \%$ \\
\hline LCO & $3.6 \%$ & $27.2 \%$ & $0.0 \%$ & $0.0 \%$ \\
\hline NMC 811 & $4.5 \%$ & $3.3 \%$ & $0.1 \%$ & $5.5 \%$ \\
\hline NMC 622 & $4.6 \%$ & $6.7 \%$ & $0.2 \%$ & $4.2 \%$ \\
\hline Legend & $<5 \%$ & $5-10 \%$ & $10-15 \%$ & $>15 \%$ \\
\hline
\end{tabular}

Fig. 7 Impact of $100 \%$ price increase in each of the individual materials on battery system cost for seven different Li-ion chemistries. A legend for the color-coding system can be seen at the bottom of the figure. Sources [52, 69, 70, 82, 83]

With this detailed breakdown of the cost variation by individual material, we can better interpret the severity of price fluctuations in different materials, across each of the seven chemistries. Even a $100 \%$ increase in the price of either manganese or nickel won't cause a battery level cost increase of greater than $10 \%$ in any of the seven chemistries. For lithium a $100 \%$ price increase is most concerning for the LFP chemistry, which is expected due to the assumption that lithium makes up the entire cathode material cost (as we have identified that LFP batteries don't contain cobalt, manganese, or nickel). Lithium is, however, present in all seven chemistries and a $100 \%$ increase in the price of lithium would therefore lead to an increase in all seven types of Li-ion batteries in the range of 3.6-11.4\%. For cobalt, it is important to note the large range in effects, as both LMO and LFP batteries contain no cobalt and are unaffected by the $100 \%$ increase in cobalt prices; however, LCO batteries, which have very high cobalt content, could experience battery level cost spikes of $27.2 \%$. Within the three different NMC chemistries, we clearly see the lessening cobalt price impact from NMC 111 to NMC 622 and NMC 811, corresponding with the lessening cobalt intensities. 


\section{Case study findings}

We find in analyzing these three case studies that the impact of material price spikes on these clean energy technology costs could potentially be disruptive to the technology's adoption. We have analyzed the fuel cell, PMG, and battery components of the PEM FCEV, direct drive wind turbine, and $\mathrm{Li}$-ion BEV technologies, respectively. For each case, we have analyzed the effect of increasing all of the selected material prices at the same rate, having $100 \%$ price spikes in individual materials, and the impact of the reoccurrence of real recent historical price events under current material intensities. Without assessing how likely each of these scenarios is, the best way to assess the severity of material price increases on these technologies is through the recent historical price event examples. For the PEM fuel cell, a $17 \%$ increase was observed under the historical scenario, and for the wind turbine PMG a $41 \%$ cost increase would have occurred. For Li-ion batteries using this method leads to a cost increase of $13 \%$ in NMC111 batteries, 14\% in NMC622 batteries, $15 \%$ in NMC811 batteries, $19 \%$ in both LCO and NCA batteries, and a decrease in cost of $2 \%$ in LMO batteries and 8\% in LFP batteries. It is difficult to determine exactly what level of cost increase would lead to disruption in technology adoption, as that entails many factors such as location, specific brand of FCEV, BEV, or wind turbine, and how much of the cost increase would be absorbed by the producer versus passed to the consumer. We speculate, however, that a large portion of these costs would be passed to the consumer and that the consumer will typically make a decision based on an expected return on investment period, which would be extended by these price increases. We therefore would suggest that these results indicate the potential for a moderate disruption in clean energy technology adoption from critical material price spikes.

\section{Implications}

\section{Overview}

The future sustainability of clean energy technologies depends on environmental, social, and economic factors. This study has established that material price spikes can impact technology costs, shifting them further from the targets of cost parity with incumbent technologies. As technology costs decrease in the future, the material prices remain mostly incompressible and therefore the materials will contribute a greater portion of the overall cost, unless dematerialization can outpace this trend. Material price spikes therefore can be expected to become even more important in the future, as they could have a proportionally greater impact then they do now.
One limitation of this method is the inability to distinguish if technology cost changes are due to material price variability, reduced material intensity (as a result of natural technological progress), or both factors acting simultaneously. Price as a metric captures a wide variety of mechanisms which may counteract one another or intensify movement in a given direction. The events that impact material price are extremely complex as they may include global political issues, physical resource scarcity, or other supply chain issues including production bottlenecks, long lead times, or improper stockpiling and hedging [84]. Through a phenomenon known as the bullwhip effect price volatility and supply issues propagate through the supply chain and have worsening impacts at the manufacturers end [84]. However, price is a leading signal that firms receive and regard as important and therefore it is the metric we've chosen to analyze. Other limitations include the assumptions taken into account in our modeling, including the calculation of our cost estimations without taking into account the time value of money and the assumption that all other component prices remain constant during critical material price events. In addition, while critical materials are by definition difficult to substitute for due to their unique properties, this work does not address the fact that if material prices were to rise high enough, some substitutions that are not currently viable may become reasonable options. It is important to note, however, that there is a long lead time for most substitution implementations, and therefore a lag time in material demand as well. For example, substitution of palladium for platinum may be possible for PEM fuel cells at certain platinum price points, as has been done in catalytic convertors that rely on platinum in the past when platinum prices rise dramatically [85]. However, studies show that platinum is still provides a "high" level of concern for automotive applications due to low elasticity and long delays in response time [23]. Future work could further explore the interplay between dematerialization and critical material price changes in an attempt to provide better predictions.

In this study, we consider the economic sustainability issues associated with relying on critical materials, but there are in fact social and environmental issues associated with the production and distribution of these materials as well. Mining is inherently an environmentally detrimental process that only becomes less efficient as resources are depleted and ore grades worsen [86]. Some of the materials, such as cobalt, are produced in regions that are known to utilize mining profits to promote conflict [87]. Recycling or secondary production of many of these critical materials is often done in developing countries under unsafe conditions, causing human health hazards [88].

In comparing our results to the previously mentioned Bloomberg New Energy Finance study, we find that our results show a lower impact of critical material costs on the 
technology but are comparable. Their results seem to show that for an NMC111 chemistry a 100\% price increase in lithium prices would lead to approximately an $8 \%$ increase in battery costs where as our results show a $5.1 \%$ increase [9]. Similarly, for a $100 \%$ increase in cobalt prices they show a $20 \%$ battery cost increase while we show $11.7 \%$, and for a $100 \%$ increase in nickel prices they show approximately a 3\% battery cost increase while we show $2.4 \%$ [9]. While these three metals in just one chemistry is only a small sample set of results that we are able to compare, it aids in supporting the methodology and results in this study.

\section{Reducing supply risk}

Given the potential for growing contributions of critical materials to clean energy technology performance and cost, future research is required to establish solutions that will reduce the underlying supply risks that may lead to price fluctuation. Factors that contribute to a material's supply risks may include difficulty of substitution due to unique properties, low recycling rates, the material being mined majorly as a byproduct of other materials, a limited number of suppliers, or the positioning of those suppliers in geopolitically unstable regions. Reducing a material's supply risk leads to a lower likelihood of price spikes, which as demonstrated throughout this study can impact the technologylevel cost. Therefore, these methods of supply risk reduction are solutions, that if applied appropriately, may improve the ability of clean energy technologies to compete economically with incumbent technologies in the marketplace (although we recognize that factors other than material costs may have a greater impact). Methods of supply risk reduction include dematerialization, substitution, recycling/using secondary sources, development of primary mining (especially for materials currently mined mainly as byproducts), yield improvement, and increasing the lifespan of products containing these materials. Each method has advantages and disadvantages, and often their use is intertwined.

Supply risk reduction measures are implemented at either the level of firms and consumers or at the policymaker and governmental level. We assume that firms and consumers are most concerned with the overall technology costs, but don't have much control over the upstream mining and processing portion of the supply chain. Therefore, the methods best suited for firms would include dematerialization, substitution, recycling, and increasing product lifespan $[89,90]$. Increasing product lifespan may be the least intuitive method of supply risk reduction, but the concept is that if a product lasts longer, it will have to be replaced with a new criticalmaterial-containing product less often, thereby reducing the demand for that material. We recognize, however, that most firms do not inherently have incentive to increase product lifespan, except possibly for customer satisfaction and brand recognition. While most of these are also outside of the reach of consumers, they should recognize that recycling (at the end of a product's life) and increasing product lifespan (through regular maintenance and repair) are methods by which they can incrementally reduce supply risk (by reducing demand). Therefore, if performed on a global scale, customers could theoretically reduce the potential for cost increases in clean energy technologies.

Dematerialization is the concept of using less of a given critical material in a specific technology per functional unit. Usually, improvements in existing technology must occur in order for dematerialization to be possible without losses to either efficiency or performance and therefore this will often happen naturally over the evolution of a product. For example, as discussed in "Case study 1: catalysts for PEM fuel cells in FCEVs" the mass of platinum in PEM fuel cells has decreased by $80 \%$ since 2005 [72]. Due to the current lower material intensities, a price event similar to that which occurred in 2008 would now lead to a $17 \%$ increase in fuel cell system costs, rather than the $30 \%$ cost increase that would have been experienced under 2008 material intensities. Often first-generation designs are created with emphasis on proof-of-concept and in later, more refined generations, we see a reduction in the use of overly expensive or risky materials [91]. Ultimately, though, firms can realize a dual benefit in dematerialization: using less material will not only reduce costs but will also reduce the impact of price spikes in the future.

The strategy of substitution involves using a different, lower impact material to replace one that is currently used. Substitution may lead to efficiency losses, as the original materials are typically chosen for their unique chemical, electrical, or physical properties that are difficult to replace. Substitution is a viable solution only when a less critical material can be substituted for a more critical one, without significant tradeoffs $[16,92,93]$. An example of this transition has been seen in the move from NMC111 battery chemistries to NMC622 and NMC811, one motivation for which is that manganese and nickel are typically considered less critical materials than cobalt, although they also have ultimately provided cost and performance benefits as well.

Recycling, or using other secondary sources such as industrial byproducts and wastes, inherently reduces supply risk because there is reduced dependence on the primary suppliers and an increased number of suppliers overall. In addition, secondary sources are often more geographically distributed. While a "closed loop" material recovery system is optimistic, even "open loop" secondary sources can offset some of the primary mining that is necessary to meet demand. For firms in particular, "in-house" recycling of scrap is a realistic method of supply risk reduction. Recycling has been deemed essential to ensure the necessary availability of materials (including platinum, lithium, and

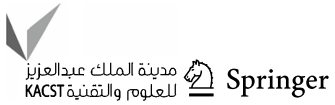


neodymium) for the clean energy transformation that is predicted in coming years [15].

It is also the recognized that a strong policy role will be required to incentivize clean energy technology adoption at a rate that will mitigate climate change. Policies that will maintain or reduce clean energy technology costs may include common incentives such as tax credits and subsidies, or less obvious supply risk mitigation efforts which help avoid cost increases. The use of policy to ensure the consistent flow of critical materials is important for not only clean energy technologies but also for other significant applications such as healthcare and defense technologies, creating additional incentive for policymakers to consider these risk reduction measures. In this respect, all the previously listed methods of supply risk reduction may be of interest, but particularly, recycling and increasing product lifespan may prove most effective. Recycling, especially increasing the recycling capacity in countries that are currently very reliant on importing these critical materials, can help nations become less reliant on imports, and thereby less susceptible to imposed tariffs or export restrictions put in place by exporting countries. These risk reduction methods would help prevent price spikes such as the 2011 rare earth price spikes that we analyzed in the wind turbine permanent magnet case study from when China implemented their export restrictions, as the USA had no domestic mine production of REEs in 2017, and 78\% of their imports were from China [35].

Other methods that indirectly fall under the scope of policy, rather than firms and consumers, may include development of new strategic mines and improving yields in mining and processing operations. These methods could be indirectly influenced through policy-backed incentives. Developing new mines can reduce supply risk by increasing the number of domestic suppliers and diversifying the geographic source of the materials. This mitigation is especially pertinent for materials that are currently mined as byproducts or coproducts of other materials. For example, currently $87 \%$ of cobalt is produced as a byproduct of copper or nickel production [94]. Therefore, an increase in demand for cobalt does not necessarily have the typical market effect of increased cobalt production. Developing primary mining for elements that are currently mined largely as byproducts or coproducts has huge economic barriers; however, it would enable market pulls and policy pushes to reduce supply risk. Yield improvement in mining or production processes would simply allow the production of greater quantities of the materials from the same ore, thereby increasing supply and lessening the material's criticality. The barriers to yield improvement are in both technological feasibility and, more often, economic feasibility, but in either case are often reduced by policy that establishes disposal bans or recycling targets for particular materials or products.

\section{Conclusions}

Through the use of historical price spike data, combined with current material intensities, we have found the impact of critical material price spikes on technology component costs to be increases of $13-41 \%$ within the three case studies considered. Therefore, we conclude that there is potential for critical material price spikes to have a moderate impact on overall clean energy technology adoption. The use of these critical materials puts clean energy technologies at some degree of risk, where that risk is a function not only of impact, as measured by the potential technology cost increases, but also probability, which can be measured through various metrics describing degrees of material criticality. By understanding criticality from previous studies, in combination with the economic modeling in this work, we can better understand where stakeholders should focus the previously discussed risk mitigation efforts to avoid disruptions in clean energy technology adoption. By removing obstacles from the pathway of clean energy technology adoption we can have a better chance at a sustainable future.

Acknowledgements National Science Foundation CBET-1254688. National Science Foundation CBET-1454166. Clean Energy Technology Graphics (Fig. 1) by Ashlee Foster.

Open Access This article is distributed under the terms of the Creative Commons Attribution 4.0 International License (http://creativeco mmons.org/licenses/by/4.0/), which permits unrestricted use, distribution, and reproduction in any medium, provided you give appropriate credit to the original author(s) and the source, provide a link to the Creative Commons license, and indicate if changes were made.

\section{References}

1. Bauer, D., Diamond, D., Li, J., Sandalow, D., Telleen, P., Wanner, B.: U.S. department of energy critical materials strategy (2010). https://energy.gov/sites/prod/files/DOE_CMS2011_FINAL_Full. pdf. Accessed 12 Feb 2019

2. Graedel, T., Nuss, P.: Employing considerations of criticality in product design. J. Mater. 66(11), 2360-2366 (2014)

3. Jin, Y., Kim, J., Guillaume, B.: Review of critical material studies. Resour. Conserv. Recycl. 113, 77-87 (2016)

4. Binnemans, K., Jones, P., Van Acker, K., Blanpain, B., Mishra, B., Apelian, D.: Rare-earth economics: the balance problem. J. Miner. Metals Mater. Soc. 65(7), 846-848 (2016)

5. Gschneidner, K., Bünzli, J., Pecharsky, V.: Handbook on the Physics and Chemistry of Rare Earths, vol 52. Elsevier, Amsterdam, NL, pp 2-276 (2010)

6. InTeGrate.: Cobalt: how disruptions in supply affect the price of a mineral resource (2018). https://serc.carleton.edu/integrate/teach ing_materials/mineral_resources/student_materials/unit 2 cobal texample.html. Accessed 12 Apr 2018

7. Olivetti, E., Ceder, G., Gaustad, G., Fu, X.: Lithium-ion battery supply chain considerations: analysis of potential bottlenecks in critical metals. Joule 1(2), 229-243 (2017) 
8. USGS.: Cobalt-mineral commodity summaries (2018). https:// minerals.usgs.gov/minerals/pubs/commodity/cobalt/mcs-2018-cobal.pdf. Accessed 25 Jan 2019

9. BNEF (Bloomberg New Energy Finance).: Lithium price spike has moderate effect on batteries (2017). https://about.bnef.com/ blog/lithium-price-spike-has-moderate-effect-on-batteries/. Accessed 23 Apr 2018

10. Bustamante, M., Gaustad, G.: Price volatility in PV-Critical Material Markets: Perspectives for Solar Firms, Consumers, and Policy Makers, 2015 IEEE 42nd Photovoltaic Specialist Conference Institute of Electrical and Electronics Engineers, New Orleans, LA (2015)

11. Candelise, C., Winskel, M., Gross, R.: Implications for CdTe and CIGS technologies production costs of indium and tellurium scarcity. Prog. Photovolt. Res. Appl. 20(6), 816-831 (2012)

12. Alonso, E., Sherman, A., Wallington, T., Everson, M., Field, F., Roth, R., Kirchain, R.: Evaluating rare earth element availability: a case with revolutionary demand from clean technologies. Environ. Sci. Technol. 46(6), 3406-3414 (2012)

13. Grandell, L., Lehtilä, A., Kivinen, M., Koljonen, T., Kihlman, S., Lauri, L.: Role of critical metals in the future markets of clean energy technologies. Renew. Energy 95, 53-62 (2016)

14. Jacobson, M.Z., Delucchi, M.A.: Providing all global energy with wind, water, and solar power, part I: technologies, energy resources, quantities and areas of infrastructure, and materials. Energy Policy 39(3), 1154-1169 (2011)

15. Bustamante, M., Gaustad, G.: Challenges in assessment of clean energy supply-chains based on byproduct minerals: a case study of tellurium use in thin film photovoltaics. Appl. Energy 123, 397-414 (2014)

16. Busche, S.: Clean energy policy analyses: analysis of the status and impact of clean energy policies at the local level. National Renewable Energy Laboratory (2010). https://www.nrel.gov/docs/ fy11osti/49720.pdf. Accessed 14 Nov 2018

17. US Department of Energy Office of Energy Efficiency and Renewable Energy.: Types of fuel cells (2018). https://www.energy.gov/ eere/fuelcells/types-fuel-cells. Accessed 7 Sept 2018

18. Fuel Cell Technologies Office.: 3.4 fuel cells. 2016 Fuel Cells Section Multi-Year Research, Development, and Demonstration Plan (2016). https://www.energy.gov/sites/prod/files/2017/05/f34/ fcto_myrdd_fuel_cells.pdf. Accessed 7 Sept 2018

19. USGS.: 2015 minerals yearbook U.S. Department of the Interior U.S. Geological Survey Platinum-Group Metals (2018). https:// minerals.usgs.gov/minerals/pubs/commodity/platinum/. Accessed 14 Sept 2018

20. Gupta, C., Maheshwari, P., Sasikala, S., et al.: Processing of pristine carbon nanotube supported platinum as catalyst for PEM fuel cell. Mater. Renew. Sustain. Energy 3, 36 (2014)

21. Gupta, C., Maheshwari, P., Sasikala, S.: Development of multiwalled carbon nanotubes platinum nanocomposite as efficient PEM fuel cell catalyst. Materials for Renewable and Sustainable Energy 5, 2 (2016)

22. Holton, O., Stevenson, J.: The role of platinum in proton exchange membrane fuel cells. Platinum Metals Rev. 57(4), 259-271 (2013)

23. Alonso, E., Field, F.R., Kirchain, R.E.: Platinum availability for future automotive technologies. Environ. Sci. Technol. 46(23), 12986-12993 (2012)

24. USGS.: Platinum-group metals (2018). https://minerals.usgs.gov/ minerals/pubs/commodity/platinum/mcs-2018-plati.pdf. Accessed 14 Sept 2018

25. Moss, R.L., Tzimas, E., Willis, P., Arendorf, J., Tercero Espinoza, L., et al.: Critical metals in the path towards the decarbonisation of the EU energy sector; assessing rare metals as supply-chain bottlenecks in low-carbon energy technologies. JRC82322, Luxembourg, EU (2013)
26. US Department of Energy.: Critical materials strategy (2011). https://energy.gov/sites/prod/files/DOE_CMS2011_FINAL_Full. pdf. Accessed 12 Feb 2019

27. Pavel, C., Lacal-Arántegui, R., Marmier, A., Schüler, D., Tzimas, E., Buchert, M., Jenseit, W., Blagoeva, D.: Substitution strategies for reducing the use of rare earths in wind turbines. Resour. Policy 52(Supplement C), 349-357 (2017)

28. Habib, K., Wenzel, H.: Exploring rare earths supply constraints for the emerging clean energy technologies and the role of recycling. J. Clean. Prod. 84(Supplement C), 348-359 (2014)

29. Moss, R., Tzimas, E., Kara, H., Willis, P., Kooroshy, J.: The potential risks from metals bottlenecks to the deployment of strategic energy technologies. Energy Policy 55(Supplement C), 556-564 (2013)

30. Hoenderdaal, S., Tercero Espinoza, L., Marscheider-Weidemann, F., Graus, W.: Can a dysprosium shortage threaten green energy technologies? Energy 49(Supplement C), 344-355 (2013)

31. Seaman, J.: Rare earths and clean energy: analyzing china's upper hand (2010). http://www.iaea.org/inis/collection/NCLCo llectionStore/_Public/42/052/42052647.pdf. Accessed 30 Nov 2017

32. Biello, D.: Rare earths: elemental needs of the clean-energy economy. https://www.scientificamerican.com/article/rareearths-elemental-needs-of-the-clean-energy-economy/ (2010). Accessed 29 Nov 2018

33. Du, X., Graedel, T.: Global rare earth in-use stocks in NdFeB permanent magnets. J. Ind. Ecol. 15(6), 836-843 (2017)

34. Hart, M.: Evaluating United States and world consumption of neodymium, dysprosium, terbium, and praseodymium in final products. M.S. Thesis, Mineral and Energy Economics, Colorado School of Mines, pp. 1-167 (2013)

35. USGS.: Rare earths (2018). https://minerals.usgs.gov/minerals/ pubs/commodity/rare_earths/. Accessed 14 Sept 2018

36. Binnemans, K., Jones, P., Blanpain, B., Gerven, T., Yang, Y., Allan, W., Buchert, M.: Recycling of rare earths: a critical review. J. Clean. Prod. 51, 1-22 (2013)

37. Etacheri, V., Marom, R., Elazari, R., Salitra, G., Aurbach, D.: Challenges in the development of advanced Li-ion batteries: a review. Energy Environ. Sci. 4(9), 3243-3262 (2011)

38. Diouf, B., Pode, R.: Potential of lithium-ion batteries in renewable energy. Renew. Energy 76(Supplement C), 375-380 (2015)

39. Battery University Group.: Types of lithium-ion batteries. http://batteryuniversity.com/learn/article/types_of_lithium_ion (2017). Accessed 18 Dec 2017

40. Potapenko, A., Chernukhin, S., Kirillov, S.: A new method of pretreatment of lithium manganese spinels and high-rate electrochemical performance of $\mathrm{Li}\left[\mathrm{Li}_{0.033} \mathrm{Mn}_{1.967}\right] \mathrm{O}_{4}$. Mater. Renew. Sustain. Energy 4, 40 (2014)

41. Andersson, B., Rade, I.: Metal resource constraints for electricvehicle batteries. Transp. Res. Part D Transp. Environ. 6(5), 297-324 (2001)

42. Gaines, L., Nelson, P.: Lithium-ion batteries: examining material demand and recycling issues. Argonne National Laboratory (2010). https://anl.box.com/s/ywkdwjaqsc61vtqkakhmhg06t m3adfgl. Accessed 30 Nov 2017

43. Stamp, A., Lang, D.J., Wäger, P.A.: Environmental impacts of a transition toward E-mobility: the present and future role of lithium carbonate production. J. Clean. Prod. 23(1), 104-112 (2012)

44. Prior, T., Wäger, P., Stamp, A., Widmer, R., Giurco, D.: Sustainable governance of scarce metals: the case of lithium. Sci. Total Environ. 461-462(Supplement C), 785-791 (2013)

45. Gruber, P., Keoleian, G., Kesler, S., Everson, M., Wallington, T.: Global lithium availability. J. Ind. Ecol. 15(5), 760-775 (2017) 
46. Institute, C.: Rechargeable batteries (2017). https://www.cobal tinstitute.org/rechargeable-batteries.html. Accessed 16 Jan 2018

47. USGS.: USGS minerals information: mineral commodity summaries (2018). https://minerals.usgs.gov/minerals/pubs/mcs/. Accessed 12 Apr 2018

48. Nassar, N., Graedel, T., Harper, E.: By-product metals are technologically essential but have problematic supply. Sci. Adv. 1(3), e1400180 (2015)

49. USGS.: Manganese statistics and information (2018). https ://minerals.usgs.gov/minerals/pubs/commodity/manganese/. Accessed 18 Apr 2018

50. Kuck, P.: Nickel statistics and information (2018). https://miner als.usgs.gov/minerals/pubs/commodity/nickel/. Accessed $18 \mathrm{Apr}$ 2018

51. Argus Media Group.: Argus rare earths monthly outlook (2016). https://www.argusmedia.com/en/metals/argus-rare-earths-month ly-outlook. Accessed 7 Jan 2019

52. InvestmentMine.: Commodity and metal prices, metal price charts (2018). http://www.infomine.com/investment/metal-price s/. Accessed 25 July 2018

53. Mineralprices.Com.: The global source for metals pricing (2018). http://mineralprices.com/. Accessed 16 Sept 2018

54. USGS.: Lithium (2018). https://minerals.usgs.gov/minerals/pubs/ commodity/lithium/. Accessed 12 Jan 2019

55. Fickling, D.: This cobalt chemistry experiment is rich with variables (2017). https://www.bloomberg.com/gadfly/articles/201709-28/cobalt-s-chemistry-experiment. Accessed 9 Jan 2018

56. Metalary.: Iron price (2019). https://www.metalary.com/iron-price 1. Accessed 11 Feb 2019

57. Infomine.: 1 year aluminum prices and price charts (2019). http:// www.infomine.com/investment/metal-prices/aluminum/1-year/. Accessed 11 Feb 2019

58. US Department of Energy Office of Fuel Cell Technology.: Hydrogen and fuel cells overview (2017). https://www.energy.gov/eere/ fuelcells/downloads/hydrogen-and-fuel-cells-overview. Accessed 1 Feb 2019

59. Arnold, R.: The lowdown on hydrogen - part 1: transportation (2017). https://energypost.eu/the-lowdown-on-hydrogen-part-1transportation/. Accessed 1 Feb 2019

60. IOP Institute of Physics.: Fuel cells. http://www.iop.org/resources/ topic/archive/fuel/index.html. Accessed 1 Feb 2019

61. Marcinkoski, J., Spendelow, J.: DOE fuel cell technologies program record (2012). https://www.hydrogen.energy.gov/pdfs/12020 fuel_cell_system_cost_2012.pdf. Accessed 1 Feb 2019

62. Chemistry Views.: Fuel cell capacity and cost trends (2013). https ://www.chemistryviews.org/details/ezine/4817371/Fuel_Cell_ Capacity_and_Cost_Trends.html. Accessed 15 Sept 2018

63. Piccirilli D.: Fact sheet-fuel cells. White Papers. EESI (2015). https://www.eesi.org/papers/view/fact-sheet-fuel-cells. Accessed 15 Sept 2018

64. McMillan, D., Ault, G.: Techno-economic comparison of operational aspects for direct drive and gearbox-driven wind turbines. IEEE Trans. Energy Convers. 25(1), 191-198 (2010)

65. Maples, B., Hand, M., Musial, W.: Comparative assessment of direct drive high temperature superconducting generators in multimegawatt class wind turbines. National Renewable Energy Laboratory (2010). https://www.nrel.gov/docs/fy11osti/49086.pdf

66. Fingersh, L., Hand, M., Laxson, A.: Wind turbine design cost and scaling model. National Renewable Energy Laboratory (2006). https://www.nrel.gov/docs/fy07osti/40566.pdf. Accessed 31 Aug 2018

67. Chertok, A., Hablanian, D., McTaggart, P., Bennett, K.: Development of a direct drive permanent magnet generator for small wind turbines (2004). https://www.osti.gov/biblio/834551. Accessed 31 Aug 2018
68. Patry, G., Romagny, A., Martinet, S., Froelich, D.: Cost modeling of lithium-ion battery cells for automotive applications. Energy Sci. Eng. 3(1), 71-82 (2014)

69. CleanTeq.: Nickel \& cobalt for lithium ion batteries (2017). http:// www.cleanteq.com/wp-content/uploads/2017/12/171205_Clean -Teq-LITHIUM-ION-BATTERIES.pdf. Accessed 11 Apr 2018

70. Lowe, M., Tokuoka, S., Trigg, T., Gereffi, G.: Lithium-ion batteries for electric vehicles: the U.S. value chain. Duke University Center on Globalization, Governance \& Competitiveness (2010)

71. Chung, D., Elgqvist, E., Santhanagopalan, S.: Automotive lithiumion battery (Lib) supply chain and U.S. competitiveness considerations. Clean Energy Manufacturing Analysis Center (2015). http://evobsession.com/wp-content/uploads/2016/01/CEMAC -Automotve-Lithium-ion-Battery-LIB-Supply-Chain-and-U.S.Competitiveness-Considerations-June-2015.pdf. Accessed 14 Jan 2019

72. US Department of Energy.: Fuel cell technologies office-FY 2017 budget at-a-glance (2016). https://www.energy.gov/sites/ prod/files/2016/03/f30/At_A_GLANCE\%20\%28FCTO\%29.pdf. Accessed 31 Aug 2018

73. Chaviaropoulos, P., Natarajan, A., Jensen, P.: Key performance indicators and target values for multimegawatt offshore turbines. European Wind Energy Association (2014). http://orbit .dtu.dk/fedora/objects/orbit:129980/datastreams/file_163e1 143-728b-49cd-81bd-8cf126eccb87/content. Accessed 31 Aug 2018

74. Battery University.: Bu-1003: electric vehicle (EV) (2018). http:// batteryuniversity.com/learn/article/electric_vehicle_ev. Accessed 18 Apr 2018

75. Chediak, M.: The latest bull case for electric cars: the cheapest batteries ever. Bloomberg Technology (2017)

76. McKinsey and Company.: Electrifying insights: how automakers can drive electrified vehicle sales and profitability. Advanced Industries (2017)

77. Metalary.: Lithium Price (2018). https://www.metalary.com/lithi um-price/. Accessed 11 Sept 2018

78. Majcher, K.: Question of the week: rare earth metals (2015). https ://www.technologyreview.com/s/535381/what-happened-to-therare-earths-crisis/. Accessed 11 Sept 2018

79. USGS.: 2011 minerals yearbook rare earths (2013). https://miner als.usgs.gov/minerals/pubs/commodity/rare_earths/myb1-2011raree.pdf. Accessed 16 Sept 2018

80. London Metal Exchange.: London metal exchange (2018). https ://www.lme.com/. Accessed 25 July 2018

81. Manthiram, A.: An outlook on lithium ion battery technology. ACS Cent. Sci. 3, 1063-1069 (2017)

82. Berckmans, G., Messagie, M., Smekens, J., Omar, N., Vanhaverbeke, L., Van Mierlo, J.: Cost projection of state of the art lithium-ion batteries for electric vehicles up to 2030. MDPI Energies 10(9), 1314 (2017)

83. Argonne National Laboratory.: Batpac: a lithium-ion battery performance and cost model for electric-drive vehicles (3.1) (2017). http://www.cse.anl.gov/batpac/about.html. Accessed 11 Apr 2018

84. Gaustad, G., Krystofik, M., Bustamante, M., Badami, K.: Circular economy strategies for mitigating critical material supply issues. Resour. Conserv. Recyc. 135, 24-33 (2017)

85. Antolini, E.: Palladium in fuel cell catalysis. Energy Environ. Sci. 2(9), 915-931 (2009)

86. Massachusetts Institute of Technology.: Mining. http://web.mit. edu/12.000/www/m2016/finalwebsite/solutions/mining.html. Accessed 4 Jan 2019

87. Home, A.: Commentary: for cobalt buyers, is artisanal mining the problem or the solution? Reuters (2018). https://uk.reuters.com/ article/uk-artisanal-mining-ahome-idUKKCN1G627E. Accessed 4 Jan 2019 
88. Williams, E., Kahhat, R., Allenby, B., Kavazanjian, E., Kim, J., $\mathrm{Xu}$, M.: Environmental, social, and economic implications of global reuse and recycling of personal computers. Environ. Sci. Technol. 42(17), 6446-6454 (2008)

89. Griffin, G., Gaustad, G., Badami, K.: A framework for firm-level critical material supply management and mitigation. Resour. Policy 60, 262-276 (2019)

90. Konitzer, D., Duclos, S., Rockstroh, T.: Materials for sustainable turbine engine development. MRS Bull. 37, 383-387 (2012)

91. Petrides, D., Papacharalampopoulos, A., Stavropoulos, P., Chryssolouris, G.: Dematerialisation of products and manufacturing generated knowledge content: relationship through paradigms. Int. J. Prod. Res. 56, 86-96 (2018)
92. Seshadri Group, UC Santa Barbara.: Materials research laboratory datamining chart (2017). http://www.mrl.ucsb.edu:8080/datam ine/hhi.jsp. Accessed 21 Nov 2017

93. Graedel, T., Barr, R., Chandler, C., Chase, T., Choi, J., Christoffersen, L., Friedlander, E., Henly, C., Jun, C., Nassar, N., Schechner, D., Warren, S., Yang, M., Zhu, C.: Methodology of metal criticality determination. Environ. Sci. Technol. 46, 1063-1070 (2012)

94. Shedd, K., Mccullough, E., Bleiwas, D.: Global trends affecting the supply security of cobalt. Min. Eng. 69, 37-42 (2017)

Publisher's Note Springer Nature remains neutral with regard to jurisdictional claims in published maps and institutional affiliations. 